\title{
DICRANOCHAETE QUADRISETA (KORŠ). NOV.\& POP. FROM AN OLIGOMINEROTROPHIC PEAT BOG IN LOWER SILESIA (SOUTH-WESTERN POLAND)
}

\author{
JAN MATUŁA \\ Department of Botany and Plant Ecology, \\ University of Agriculture \\ Cybulskiego 32, 50-205 Wrocław, Poland \\ e-mail:matula@ozi.ar.wroc.pl
}

(Received: June 3, 2004. Accepted: November 18, 2004)

\begin{abstract}
Dicranochaete quadriseta (Korš.) Nov. \& Pop. was collected during investigations of algae from mountain peat bogs of the Sudeten Mts (Poland). The paper describes the morphology, taxanomy, geographical distribution and ecological conditions of this species. This very rare species was found in an oligominerotrophic peat bog called "Topieliska-Zieleniec” near Duszniki (Orlickie Mts).
\end{abstract}

KEY WORDS: Chlorophyceae, Gloedendrales, Dicranochaete, morphology, taxonomy, ecology, geographical distribution.

\section{INTRODUCTION}

In algae samples, collected in the years 1980-1989 in the Sudeten Mts, identified was the green alga Dicranochaete bohemia Nov. \& Pop. (Matuła 1992). Among specimens typical for that species in the peat bog "Topieliska-Zieleniec" near Duszniki found were numerous individuals, which at the apex cell were distinctly elongated into a cone-shaped projection (Matuła 1992, Figs 11, 12, 20-22). In the mentioned peat bog and in the same habitats and in different vegetation seasons each time found were both specimens typical for this species (cells showing at apex hyaline opercula limited at the border by a wavy corolla), and also firms additionally equipped with a single, pointed projection at the cell apex.

In the above-mentioned paper, the latter specimens were recognized as $D$. bohemica forms, since they showed with it a high similarity in respect of many features, and also by reason of their permanent occurrence in company of cells typical for that taxon.

However, further observations performed on new material gained in the years 1995, 1996 and 2000, induce to reconsider that opinion.

From among the genus Dicranochaete, a complete descriptive documentation by use of optical microscopy as well as transmission and scanning microscopy, have three species: D. reniformis Hieron., D. bohemica Nov. \& Pop., and D. quadriseta (Korš.) Nov. \& Pop. Of particular value are the results of sub microscopic investigations obtained by Van De Wiel and Reymond (1983), and Francke and Kooijman-Von Blokland (1985).
In accordance with the hitherto knowledge, and particularly with data on sub microscopic structure of algae of the genus Dicranochaete given by the mentioned above authors, the collected in the peat bog "Topieliska-Zieleniec" specimens with a pointed projection at apex call, should be recognized as D. Quadriseta (Korš.) Nov. et Pop.

This green alga was developing during the whole vegetative season in all the years of study. It was most often found in strongly hydrated, oligominerotrophic habitats, overgrown by Sphagnum riparium Angstr., S. fallax (Klinggr.) Klinggr., S. squarrosum Crome, Eguisetum palustre L. Juncus offusus L., J. inflexus L., Carex curta Good., C. nigra (L.) Reichard, Calamagrostis villosa (Chaix) J.F. Gmel, Eriophorum angustifolium Honck.

The depth of water during the vegetative season ranged from +5.0 to $1.0 \mathrm{~cm}$; the $\mathrm{pH}$ ranged from 4.2 to 4.65 , conductivity from 62 to $96 \mu \mathrm{S}$. The contens of the main nutrients (in $\mathrm{mg} / \mathrm{L}$ ) were as follows: $\mathrm{N}-\mathrm{N}-\mathrm{NH}_{4}: 0.59-0.99$; $\mathrm{N}-\mathrm{NO}_{3}$ : 0.005-0.01; 4.1-7.9; Mg: 0.5-1.1; K: 04-0.91.

\section{RESULTS}

The cells occur most often single, surrounded by a mucilaginous envelope. This species sometimes forms small colonies (Figs 1,6). Cell shapes viewed from above circular, viewed from the side bulbous, rarely flattened, and loaf-like (Figs 2, 3). At apex cell there occurs a single cone-shaped, pointed projection (Figs 2-5). The mucilaginous envelopes are hyaline, sometimes slightly pink, broad viewed from the side they assume a bell-shape. Cell walls thick. 


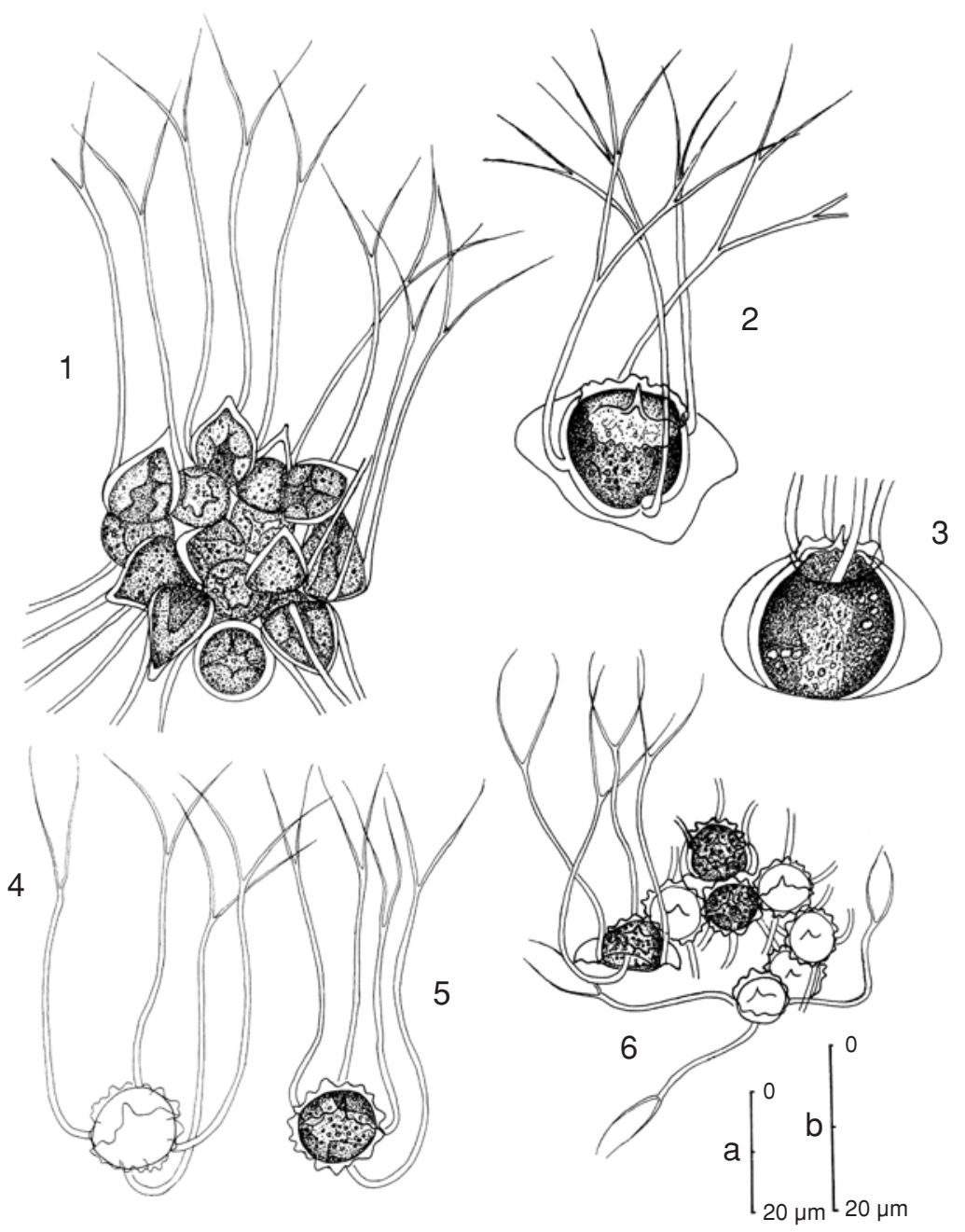

Figs 1-6. Dicranochaete quadriseta (Korš.) Nov. \& Pop. Fig. 1. Small colony consists of several young cells Figs 2, 3. Vegetative cells seen from the siede: a part from hyaline corolla on the cell apex, a cone-shaped projection emerges.

Figs 4-6. Young vegetative cells rounded in shape with hyaline corolla, and cone-shaped projection on the cell apex (seen from above).

Figs 4-6 enlargement a; Figs 1-3 enlargement b.
The external wall layers in apex part of the call evolve into a smooth or slightly wavy, hyaline, low corolla, well visible particularly in young specimens (Figs 4-6). The upper edge of corolla is cut straight or irregularly incsed. In older specimens the corolla is very low, winds around the cell in shape of a thin rim. The alga has four cross-wisely arranged, dichotomously branched setae; specimens with three or two setae were also met. The setae in very young cells were most often unbranded. The features of the internal cell structure correspond with hitherto literature descriptions of this species.

Cell dimensions: cell width at the basis 7-20 $\mu \mathrm{m}$; length of cone-shaped projection 1-3 $\mu \mathrm{m}$; length of bristles 60-145 $\mu \mathrm{m}$.

Habitat: on shoots and leaves Sphagnum, and among masses of other algae in deeper hollows and pools filled with water up to $5 \mathrm{~cm}$ in depth.

Geographical distribution: European part of Russia, France, Netherlands, Poland.

This species was discovered by Koršikov (1953) in a peat bog overgrown by Sphagnum in the European part Russia. Bourrelly (1966) mentioned also the occurrence of this species in France, also in peat bogs. It was discovered in several stands in Holland by Francke and Kooijman-Van Blokland (1985). The discovery in the peat bog "Topieliska-Zieleniec" is the fourth stand in the world of that rare species.

\section{LITERATURE CITED}

BOURRELLY P. 1966. Les algues d' eau douce. Tome I: Algues Vertes. Paris.

FRANCKE J.A., KOOIJMAN-VAN BLOKLAND H. 1985. Species Delimitation within Green Alagl Genus Dicranochaete Hieronymus. Arch. Protistenk. 130: 93-102.

KORŠIKOV O.A. 1953. Podklad Protokokovi (Protococcineae) Vakuol'ni (Vacuolales) ta Protokokovi (Protoccales). Viz. prisnovod. Vodor. URSR 5: 1-437 Akad. Nauk URSR, Kiiv.

MATUŁA J. 1992. Dicranochaete species (Chlorophyceae, Gloeodendrales) in peat bogs of Lower Silesia (South western Poland). Archiv. F. Hydrobiol., Suppl. Bd. 93, Algological Stud. 65: 63-72.

VAN DE WIEL C.M., REYMOND O.L. 1983. Ultrastructure and taxonomic position of the green alga Dicranochaete reniformis Hieronymus. Phycologia 22 (3): 317-324. 